Folia Cardiologica 2015

\title{
Diety roślinne w kontekście chorób układu sercowo-naczyniowego
}

\section{Plant-based diet in the context of cardiovascular disease}

\author{
Damian Parol $^{1}$, Artur Mamcarz ${ }^{2}$ \\ ${ }^{1}$ Dietetyk sportowy \\ ${ }^{2}$ III Klinika Chorób Wewnętrznych i Kardiologii II Wydziału Lekarskiego Warszawskiego Uniwersytetu Medycznego
}

\section{Streszczenie}

Rozwiązanie rosnącego problemu chorób układu sercowo-naczyniowych jest jednym z głównych zadań współczesnej nauki o żywieniu człowieka. Związek między chorobami układu krążenia a sposobem odżywiania gruntownie przebadano. Szkodliwy wpływ przypisuje się diecie bogatej w nasycone kwasy tłuszczowe, a także cholesterolowi i zbyt dużej podaży soli kuchennej oraz sacharozy. Dane epidemiologiczne sugerują, że weganie i wegetarianie rzadziej zapadają na choroby układu sercowo-naczyniowego niż osoby na diecie dopuszczającej produkty odzwierzęce. Również dane eksperymentalne wskazują efekt terapeutyczny diet roślinnych. Problem ma kompleksową strukturę - wiele czynników oraz produktów żywieniowych może wpływać na rozwój choroby. Jednocześnie, obok pozytywnych aspektów diet roślinnych, mogą się one wiązać ze zwiększeniem narażenia na niektóre czynniki ryzyka, takie jak na przykład hiperhomocysteinemia wywołana niedoborem kobalaminy (witaminy $\mathrm{B}_{12}$ ) czy zły stan odżywienia długołańcuchowymi, wielonienasyconymi kwasami tłuszczowymi omega 3.

Słowa kluczowe: wegetarianizm, weganizm, diety roślinne, miażdżyca, choroby układu sercowo-naczyniowego, cholesterol

(Folia Cardiologica 2015; 10, 2: 92-99)

\section{Wstęp}

W Polsce z powodu zawału serca umiera około 100 osób dziennie, a choroby układu sercowo-naczyniowego stanowią przyczynę prawie połowy wszystkich zgonów [1].

Należy zauważyć, że główna przyczyna zgonów w Polsce i na świecie w krajach zachodnich w mniejszym stopniu dotyka osoby eliminujące lub ograniczające produkty pochodzenia zwierzęcego. Przeprowadzona przez Huanga i wsp. [2] metaanaliza badań kohortowych z Wielkiej Brytanii, Stanów Zjednoczonych, Niemiec, Holandii i Japonii obejmująca 124706 uczestników wykazała, że śmiertelność z powodu chorób układu krążenia była u wegetarian niższa o 16\% niż u niewegetarian, z kolei ryzyko zgonu z powodu choroby niedokrwiennej serca było niższe o 29\%. Czynniki ryzyka, takie jak wartość wskaźnika masy ciała (BMI, body mass index) oraz stężenia cholesterolu całkowitego, lipoprotein o małej gęstości (LDL, low-density lipoprotein) i apolipoproteiny B są niższe u wegetarian, szczególnie wegan, niż u niewegetarian [3]. Stężenia lipoprotein A-I i o dużej gęstości (HDL, high-density lipoprotein) pozostają bez zmian u wegetarian w porównaniu z osobami jedzącymi mięso, natomiast u wegan stężenie HDL jest niższe. Grubość kompleksu błona środkowa-śródbłonek (IMT, intima-media thickness) w tętnicy szyjnej jest mniejsza u osób na diecie wegetariańskiej [4] niż u niewegetarian. Zwiększona grubość IMT świadczy o rozwoju zmian miażdżycowych i jest silnie związana z ryzykiem rozwoju chorób układu sercowo-naczyniowego w przyszłości [5].

Adres do korespondencji: mgr Damian Parol, Fitness Club Imperium, ul. Kołłątaja 48, 05-402 Otwock, tel.: 227792323 ,

e-mail: parol.damian@gmail.com 
Zaproponowany przez Ornisha i wsp. [6, 7] ponad 20 lat temu program obejmujący między innymi niskotłuszczową (do 10\% energii), wysokowęglowodanową (70-75\% energii) dietę opartą na niskoprzetworzonych produktach roślinnych jest jedną z nieoperacyjnych metod regresji zmian miażdżycowych. Istotny pozostaje fakt, że program ten nie jest z definicji wegetariański, ale cechujący go bardzo niski limit spożycia cholesterolu (5 mg/d.) $[6,7]$ wymusza silne ograniczanie spożycia produktów odzwierzęcych oraz uwzględnia suplementację rybim olejem. Po roku u osób z programu Ornisha i wsp. zaobserwowano obniżenie stężenia cholesterolu całkowitego z 225,1 mg/dl do 162,9 mg/dl, natomiast w grupie kontrolnej, poddanej standardowej terapii, stężenie to obniżyło się bardzo nieznacznie. W tętnicach wieńcowych osób z grupy eksperymentalnej obserwowano cofnięcie się zmian miażdżycowych po roku i po 5 latach terapii, natomiast w grupie kontrolnej stwierdzono progresje choroby [6, 7]. Program Ornisha i wsp. jest na tyle skuteczny, że w Stanach Zjednoczonych niektóre szpitale proponują go pacjentom zamiast operacji kardiochirurgicznych. Również wyniki nowszych badań wskazują na korzystny wpływ diet opartych na produktach roślinnych.

Terapeutyczny efekt diety roślinnej potwierdzono w badaniach klinicznych. W grupie 35 kobiet, w wieku 22-48 lat, wprowadzono niskotłuszczową (10\% energii z tłuszczu) wegetariańską dietę, co po 4 cyklach miesiączkowych przyniosło efekt w postaci obniżenia wartości cholesterolu całkowitego o 16,8\%, cholesterolu frakcji LDL - o 16,5\%, a cholesterolu frakcji HDL - o 13,2\% [8]. Inne badanie przeprowadzono w grupie 291 osób, w tym u 142 wprowadzono niskotłuszczową dietę wegańską bez restrykcji kalorycznej. Po 18 tygodniach w grupie kontrolnej stwierdzono niewielkie zmniejszenie masy ciała i bardzo niewielkie korzystne zmiany w profilu lipidowym, natomiast w badanej grupie stwierdzono spadek masy ciała o 4,3 kg oraz obniżenie stężenia cholesterolu całkowitego o $13,7 \mathrm{mg} / \mathrm{dl}$, frakcji LDL zaś - o 13,0 mg/dl [9].

Z kolei w badaniu obejmującym grupę chorych na cukrzycę typu 2 wykazano, że niskotłuszczowa dieta wegańska może być korzystniejsza od diety rekomendowanej przez American Diabetes Association (ADA). Wyniki publikowano 2-krotnie - po 22 [10], a następnie po 74 tygodniach [11]. W badaniu wzięło udział 99 osób - 49 z grupy badanej i 50 z kontrolnej. Po 74 tygodniach osoby na diecie wegańskiej schudły o więcej kilogramów (-4,4 v. -3 kg), ponad 2-krotnie bardziej obniżył się u nich odsetek hemoglobiny glikowanej $\left(\mathrm{HbA}_{1 \mathrm{c}} ;-0,34\right.$ v. $\left.-0,14 \%\right)$, straciły więcej w obwodzie tali $(-4,2$ v. $-1,8 \mathrm{~cm})$, w większym stopniu obniżyły się u nich stężenia glukozy na czczo (-19,5 v. -14 mg/dl), cholesterolu całkowitego (-21,6 v. -14,8 mg/dl) i triglicerydów (-33,9 v. - 7,8 mg/dl) oraz bardziej obniżyło się u nich ciśnienie rozkurczowe (-3,9 v. $-2,7 \mathrm{~mm} \mathrm{Hg})$.

Wyniki badania przeprowadzonego przez Kahleova [12] u 74 chorych na cukrzycę typu 2, których losowo przydzielono do grupy na diecie wegetariańskiej lub do grupy kontrolnej, również wskazują na terapeutyczny efekt diety roślinnej. Grupie na diecie wegetariańskiej zalecono przestrzeganie diety opartej na warzywach, w tym strączkowych, zbożach, orzechach i owocach. Produkty odzwierzęce ograniczono do jednej porcji jogurtu niskotłuszczowego dziennie. Na energetyczność diety składały się w 60\% węglowodany, w 15\% białka oraz w 25\% tłuszcze. Grupa kontrolna pozostawała na diecie zgodnej z wytycznymi European Association for the Study of Diabetes (EASD), na której energetyczność składały się w 50\% węglowodany, w 20\% białka oraz w 30\% tłuszcze. Obie diety zawierały $500 \mathrm{kcal}$ mniej niż wynosiło zapotrzebowanie badanych. Po 6 miesiącach w grupie na diecie wegetariańskiej zauważono większy spadek stężeń cholesterolu całkowitego (-4,5 v. $-1,55 \mathrm{mg} / \mathrm{dl}$ ) oraz frakcji LDL (-6.57 v. $-5,41 \mathrm{mg} / \mathrm{dl}$ ) oraz znaczniejsze obniżenie wartości $\mathrm{HbA}_{1 \mathrm{c}}(-7 \mathrm{v} .-2 \mathrm{mmol} / \mathrm{mol})$ i BMI $\left(-2,18\right.$ v. $\left.-0,98 \mathrm{~kg} / \mathrm{m}^{2}\right)$.

W świetle powyższych informacji dobrze zaprojektowana dieta roślinna jest skutecznym narzędziem obniżania ryzyka chorób układu sercowo-naczyniowego oraz może być metodą leczniczą.

\section{Rola ograniczenia produktów odzwierzęcych}

Korzyści płynące z diet roślinnych mogą wynikać z ograniczenia spożycia produktów odzwierzęcych, zwłaszcza bogatych w nasycone kwasy tłuszczowe i cholesterol. Należą do nich mięso (szczególnie czerwone), tłuste produkty mleczne (sery żółte, śmietana, masło) i jaja.

\section{Mięso}

Dane obserwacyjne sugerują, że znaczne spożycie czerwonego i przetworzonego mięsa może sprzyjać chorobom układu sercowo-naczyniowego $[13,14]$ oraz chorobom towarzyszącym - otyłości [15, 16] i cukrzycy [17]. Poza cholesterolem i nasyconymi kwasami tłuszczowymi, które uznaje się za przyczynę chorób układu sercowo-naczyniowego [18], w czerwonym mięsie występują również I-karnityna oraz żelazo hemowe, a z najnowszych danych obserwacyjnych wynika, że mogą one sprzyjać chorobom układu krążenia. Występująca w znacznych ilościach w czerwonym mięsie I-karnityna, podobnie jak cholina, jest metabolizowana do tlenku trimetyloaminy (TMAO, trimethylamine oxide) [19], który sprzyja rozwojowi zmian miażdżycowych [20], jednak dowody w tej kwestii są niespójne. Metaanaliza przeprowadzona przez DiNicolantonio i wsp. [21] sugeruje, że podawanie I-karnityny pacjentom po zawale serca zmniejsza śmiertelność z wszystkich przyczyn o 27\%, redukuje prawdopodobieństwo częstoskurczu komorowego o 67\%, a dławicy piersiowej - o 40\%, ale nie zmniejsza prawdopodobieństwa niewydolności serca ani ponownego zawału serca. Dodatkowo dane epidemiologiczne sugerują, że spożycie przetworzonego mięsa jest silniej związane z chorobami 
układu sercowo-naczyniowego niż spożycie mięsa nieprzetworzonego, natomiast I-karnityna występuje w nim mniejszej ilości niż w mięsie nieprzetworzonym [13, 14]. Innym komponentem czerwonego mięsa, mogącym sprzyjać ryzyku chorób układu sercowo-naczyniowego, jest żelazo hemowe. W badaniach epidemiologicznych powiązano znaczne spożycie żelaza hemowego z częstszymi przypadkami chorób układu krążenia i cukrzycy typu 2 [22, 23]. Natomiast niższe ryzyko cukrzycy typu 2 obserwuje się u osób o małych zapasach żelaza oraz regularnie oddających krew [24]. Prawdopodobnie rola czerwonego mięsa w rozwoju zmian miażdżycowych jest bardziej kompleksowa niż wynikałoby to z samej zawartości cholesterolu i nasyconych kwasów tłuszczowych.

\section{Produkty mleczne}

Niektóre produkty mleczne zawierają znaczną ilość nasyconych kwasów tłuszczowych oraz cholesterolu (np. ser żółty i twarogowy, masło, jogurt typu greckiego, śmietana). Inne produkty (np. odtłuszczony jogurt i ser twarogowy) zawierają ich stosunkowo niewielką ilość. Dlatego wpływ produktów mlecznych na choroby układu sercowo-naczyniowego może być bardzo różny zależnie od zawartości tłuszczu. Z przeglądu badań Huth i Park [25] wynika, że spożycie produktów mlecznych może nie wpływać na ryzyko chorób układu sercowo-naczyniowego, jednak niektóre badania wskazują na niekorzystny wpływ masła i tłuszczu mlecznego ogółem na czynniki ryzyka tych schorzeń. Ostatecznie wpływ produktów mlecznych oraz zawartego w nich tłuszczu na choroby układu krążenia pozostaje niejednoznaczny. Odtłuszczone produkty mleczne wydają się bezpieczne z punktu widzenia chorób układu sercowo-naczyniowego, jednak włączenie do diety ich tłustych odpowiedników i masła nie jest wskazane.

\section{Jaja}

Spożywanie jaj, jako produktu bogatego w cholesterol, często jest kojarzone z chorobami układu sercowo-naczyniowego. Jaja w istotny sposób podwyższają stężenie cholesterolu całkowitego we krwi oraz obniżają stosunek HDL do LDL [26]. Innym czynnikiem, który może zwiększać ryzyko chorób układu sercowo-naczyniowego obecnym w jajach, jest cholina. Podobnie jak I-karnityna jest ona metabolizowana przez flore jelitowa, a następnie wątrobę do TMAO. Powyższe przesłanki są częściowo spójne z danymi epidemiologicznymi. W trzech opublikowanych w 2013 roku metaanalizach [27-29] wykazano dodatnią korelację między chorobami układu krążenia a spożyciem jaj. Li wsp. [27] zauważyli, że spożycie 4 jaj tygodniowo wiązało się ze zwiększonym o 6\% ryzykiem chorób układu sercowo-naczyniowego. Związek ten był jeszcze silniejszy u chorych na cukrzycę i taka sama liczba jaj zwiększała wspomniane ryzyko o 40\%. Jednocześnie należy zauważyć, że spożycie jaj może również sprzyjać rozwojowi cukrzycy typu 2 [30-32]. Natomiast związek między spożyciem jaj a chorobami układu sercowo-naczyniowego u osób bez cukrzycy nie został stwierdzony w dwóch pozostałych metaanalizach [28, 29]. Sugeruje to, że powinno się odradzać spożycie jaj chorym na cukrzycę typu 2.

\section{Rola włączenia produktów roślinnych}

Korzyści płynące z diety roślinnej mogą też wynikać z włączenia do diety produktów roślinnych oraz zawartych w nich substancji, takich jak frakcje błonnika i kwasów tłuszczowych, białka roślinne, witaminy, składniki mineralne, izoflawony oraz inne przeciwutleniacze i fitozwiązki.

\section{Warzywa strączkowe}

Ze względu na zawartość białka oraz właściwości kulinarne osoby na diecie roślinnej często szukają substytutów mięsa w postaci warzyw strączkowych. Wykazano, że ich spożycie, w tym soi, wpływa pozytywnie na profil lipidowy krwi [33, 34]. Metaanaliza badań z randomizacją, prospektywnych badań kohortowych oraz badań kliniczno-kontrolnych dowiodła, że spożycie 100-gramowej porcji warzyw strączkowych (< 1/2 typowej puszki) 4 razy w tygodniu wiąże się ze zmniejszonym o 14\% ryzykiem choroby niedokrwienna serca [35].

Warzywa strączkowe są z jednej strony dobrym źródłem błonnika oraz witamin i składników mineralnych, przy zachowaniu stosunkowo niewielkiej gęstości energetycznej, z drugiej natomiast mogą wypierać produkty odzwierzęce jako kulinarna alternatywa dla mięsa i jego przetworów.

\section{Soja}

Wyjątkowym z kilku powodów warzywem z rodziny strączkowych jest soja. Ma ona szereg zastosowań kulinarnych i można z niej tworzyć zamienniki mięsa, sera oraz innych przetworów mlecznych; zawiera białko o wysokiej wartości biologicznej oraz znaczną ilość aktywnych biologicznie izoflawonów. W przeszłości brano pod uwagę możliwość wpływu soji lub jej składników na ryzyko chorób układu sercowo-naczyniowego w wyniku modyfikacji takich czynników, jak ciśnienie tętnicze, profil lipidowy czy stężenie apolipoproteiny A-l. Obecnie wydaje się, że soja wykazuje korzystny wpływ na stężenie LDL, szczególnie jeśli zastępuje w diecie produkty odzwierzęce [34]. Jej wpływ na wartości apolipoproteiny A-I, HDL oraz cieśnienie jest trudny do określenia [34, 36]. Ponadto w jednym z badań klinicznych stwierdzono, że podanie przekąski w postaci orzeszków sojowych w porównaniu z przekąską o zbliżonym składzie kalorii i makroskładników poprawia funkcjonowanie śródbłonka [37].

Soja wydaje się dobrą alternatywą dla mięsa i niektórych produktów nabiałowych w prewencji chorób układu sercowo-naczyniowego również ze względu na brak cholesterolu, niską zawartość nasyconych kwasów tłuszczowych, wysoką zawartość wielonienasyconych kwasów tłuszczo- 
wych, pełnowartościowego białka i błonnika oraz możliwość upodobnienia do produktów odzwierzęcych.

\section{Pełnoziarniste produkty zbożowe}

Badania epidemiologiczne wskazują, że spożycie pełnoziarnistych produktów zbożowych może sprzyjać obniżeniu ryzyka wystąpienia chorób układu sercowo-naczyniowego $[38,39]$. Natomiast w badaniach eksperymentalnych za pomocą diety bogatej w pełnoziarniste produkty zbożowe udawało się obniżyć ciśnienie tętnicze [40]. W pracy przeglądowej z 2010 roku Fardet [41] wskazuje na kilkadziesiąt substancji obecnych w produktach pełnoziarnistych, które mogą korzystnie działać na zdrowie sercowo-naczyniowe. Między innymi są to składniki mineralne, witaminy, kwasy tłuszczowej, poszczególne frakcje błonnika oraz przeciwutleniacze.

\section{Warzywa i owoce}

Przegląd badań klinicznych, przygotowany przez Hartley i wsp. [42], sugeruje pozytywny wpływ zwiększenia spożycia warzyw i owoców na ciśnienie skurczowe i rozkurczowe oraz stężenie LDL. Podobne wnioski płyną z badań nad związkiem między spożyciem warzyw i owoców a umieralnością z powodu chorób układu sercowo-naczyniowego. Metaanaliza badań prospektywnych przygotowana przez Wang i wsp. [43], która objęła 16 prospektywnych badań kohortowych, z łączną liczbą 833234 uczestników i 11512 zgonów z przyczyn sercowo-naczyniowych, sugeruje związek między spożyciem owoców i warzyw a chorobami układu krążenia. Badacze zauważyli, że 1 porcja (tj. 80 g owoców; 77 g warzyw) obniża ryzyko zgonu z powodu choroby układu sercowo-naczyniowego o odpowiednio 5\% i 4\%. Interesującym jest, że obserwuje się silniejszy protekcyjny efekt owoców niż warzyw.

Powodem protekcyjnego wpływu owoców i warzyw może być zawartość witaminy $\mathrm{C}$, flawonoidów i innych fitozwiązków o działaniu antyoksydacyjnym oraz potasu i magnezu. Rolę odgrywa również obniżenie ciśnienia tętniczego, której sprzyja dieta zawierająca duże ilości warzyw i owoców [44].

\section{Orzechy}

Dane z badania kohortowego Nurses' Health Study sugerują odwrotny związek między spożyciem orzechów a umieralnością na choroby układu sercowo-naczyniowego [45]. Do podobnych wniosków doszli Afshin i wsp. [35], analizując dostępne badania prospektywne i eksperymentalne. Badacze ci zauważyli, że częstość występowania choroby niedokrwiennej serca jest mniejsza o 22-24\% u osób spożywających 4 razy w tygodniu porcję około 28 g orzechów. Jednak nie stwierdzono takiego związku w odniesieniu do udaru ani żadnego $z$ jego rodzajów.

Wnioski te są spójne z przeglądem przygotowanym przez Mukuddem-Petersen i wsp. [46], którzy stwierdzili, że spożycie 50-100 g orzechów 5 razy w tygodniu wpływa na obniżenie stężeń cholesterolu całkowitego oraz frakcji LDL u pacjentów z prawidłowymi i wysokimi wartościami cholesterolu. Natomiast autorzy zbiorczej analizy badań interwencyjnych zauważyli, że dodanie orzechów do diety tym bardziej skutecznie obniża stężenie cholesterolu we krwi, im jest on wyższe początkowo [47]. Biorąc pod uwage fakt, że jest to bardzo prosta i tania interwencja dietetyczna, można rekomendować spożywanie orzechów osobom obarczonym podwyższonym ryzykiem chorób układu sercowo-naczyniowego, które niechętnie wprowadzają inne istotne zmiany $\mathrm{w}$ diecie.

W badaniach eksperymentalnych wykazano, że podanie orzechów brazylijskich poprawia profil lipidowy, obniżając stężenia cholesterolu całkowitego i frakcji LDL, ale także wartość szczególnie groźnych - utlenionych LDL (ox-LDL) [48]. Interesujące jest, że pozytywny efekt takiego działania może się utrzymywać przez miesiąc po jednorazowym podaniu jedynie 4 orzechów (20 g) i jest większy niż przy dawce $50 \mathrm{~g}$ [49].

Korzystny wpływ spożywania orzechów w prewencji chorób układu sercowo-naczyniowego nie wynika tylko z ich zdolności do obniżania cholesterolu. W doświadczeniach, w których badanym włączono do diety orzechy włoskie lub laskowe, zauważono poprawę funkcjonowania śródbłonka naczyń krwionośnych badanych za pomocą (FMD, flow-mediated dilatation) [50-52]. Obawy może budzić wysoka kaloryczność orzechów, jednak w wielu pracach nie zaobserwowano zwiększenia masy ciała po dodaniu orzechów do diety lub był on bardzo nieznaczny w stosunku do liczby spożytych w nich kalorii [53]. W jednym z doświadczeń porcja 54 g orzechów włoskich (wartość kaloryczna 366 kcal) nie spowodowała żadnego zwiększenia masy ciała [51]. Dane eksperymentalne potwierdzają również obserwacje epidemiologiczne [54]. Wyjaśnieniem tego fenomenu jest zmniejszone spożycie kalorii z innych źródeł, utrata energii z kałem oraz przyspieszona przemiana materii [55].

\section{Gluten}

Inny kulinarny zamiennik mięsa to białko pszenne. Jest ono popularne, ponieważ łatwo nadać mu smak i konsystencję mięsa. Dodatek białka pszennego (glutenu) do diety osób z hiperlipidemią pozwolił obniżyć stężenkia ox-LDL, triglicerydów oraz kwasu moczowego [56]. W innym badaniu zauważono, że wprowadzenie większej liczby produktów zawierających gluten obniżyło wartości triglicerydów o 13\%, nie wpływając na stężenia HDL i LDL [57]. Należy zauważyć, że - ze względu na problem nierozpoznanej celiakii oraz nietolerancji glutenu niezwiązanej z celiakią - dodania glutenu do diety nie można zalecać każdemu. Mimo to dla osób bez tych dolegliwości może on stanowić znakomity zamiennik produktów mięsnych, ponieważ można mu nadać podobny smak i teksturę. 


\section{Czynniki zwiększające ryzyko chorób układu sercowo-naczyniowego związane z dietą roślinną}

Mimo oczywistych korzyści dieta roślina może również spowodować nasilenie niektórych czynników ryzyka związanych z chorobami układu sercowo-naczyniowego, takich jak niedobory witaminy $B_{12}$ oraz małe spożycie kwasów tłuszczowych omega 3.

\section{Niedobór witaminy $\mathrm{B}_{12}$}

Witamina $\mathrm{B}_{12}$ jest jedyną witaminą występującą wyłącznie w produktach odzwierzęcych. W związku z tym osoby na diecie wegańskiej muszą tę witaminę suplementować lub korzystać z żywności fortyfikowanej, by uchronić się przed niedoborami. Nieprawidłowy stan odżywienia witaminą $\mathrm{B}_{12}$ mierzony metodami referencyjnymi (stężenia holotranskobalaminy II lub kwasu metylomalonowego w osoczu lub moczu) wynosi 32-61\% zależnie od badanej populacji [58].

Niedobór witaminy $\mathrm{B}_{12}$ sprzyja podwyższonemu stężeniu homocysteiny. Natomiast podwyższona wartość homocyteiny jest czynnikiem ryzyka chorób układu sercowo-naczyniowego [59]. Hipotetycznie może to powodować, że osoby na diecie wegańskiej i niesuplementujące witaminy $\mathrm{B}_{12}$ będą bardziej narażone na choroby układu krążania lub że korzystny efekt diety roślinnej zostanie u nich częściowo zniesiony. Należy więc edukować osoby zmieniające dietę na roślinną co do potrzeby suplementacji witaminą $\mathrm{B}_{12}$.

Potwierdzają to badania wskazujące na związek między niedoborem witaminy $\mathrm{B}_{12}$ a grubszym IMT i niższym FMD w porównaniu z osobami, u których stężenie witaminy $B_{12}$ jest prawidłowe [60]. Istotny jest fakt, że to stan odwracalny - doświadczenia wskazują, że suplementacja witaminą $\mathrm{B}_{12}$ może poprawić funkcjonowanie naczyń krwionośnych u osób z jej niedoborem [60].

\section{Kwasy tłuszczowe omega 3}

Tłuste ryby morskie, które wyklucza się z diet wegetariańskich, są dobrym źródłem kwasów tłuszczowych omega 3. Wyniki badań wskazują, że kwasy te wpływają na ryzyko sercowo-naczyniowe poprzez obniżanie tętna i ciśnienia tętniczego, ograniczenie stanu zapalnego, poprawę funkcjonowania śródbłonka, stabilności blaszki miażdżycowej oraz insulinowrażliwości [61]. Niektóre badania sugerują, że szczególną rolę odgrywa kwas dokozaheksaenowy (DHA, docosahexaenoic acid) i że jego niższe stężenie w surowicy może korelować z wyższym ryzykiem chorób układu sercowo-naczyniowego [62]. Przegląd badań przygotowany przez Lane i wsp. [61] wskazuje, że możliwe jest zwiększenie stężenia kwasu eikozapentaenowego (EPA, eicosapentaenoic acid) w surowicy za pomocą oleju Inianego, ze żmijowca oraz orzechów włoskich, ale nie udało się zwiększyć stężenia DHA za pomocą tych produktów. Spośród źródeł roślinnych najbardziej efektywnym, umoż- liwiającym podwyższenia wartości DHA w surowicy, jest olej z mikroalg morskich. W celu zapewnienia jego odpowiedniej ilości wegetarianie powinni wykorzystywać jego roślinną frakcję - kwas alfa-linolenowy (ALA, alpha-linolenic acid). Można go znaleźć w takich produktach, jak siemię Iniane, nasiona chia, orzechy włoskie oraz olej rzepakowy. Należy również rozważyć możliwość suplementacji mikroalgami morskimi lub olejem rybim.

Innym dobrym wyborem wydaje się, już wymienione, siemię Iniane. W eksperymencie w grupie 110 osób wykazano, że siemię Iniane podane w dawce 30 g dziennie przez 6 miesięcy może obniżyć ciśnienie u osób z nadciśnieniem tętniczym [63]. W innych badaniach dowiedziono również korzystnego wpływu tego produktu na gospodarkę lipidową [64], obniżenie stężenia apolipoproteiny A-I, ciśnienia tętniczego oraz stężenia białka C-reaktywnego [65]. Dodatkowo w doświadczeniach na królikach stwierdzono cofanie się zmian miażdżycowych po włączeniu do diety siemienia Inianego [66]. Należy zauważyć, że wymienione wyżej efekty zdrowotne są charakterystyczne dla całych ziaren siemienia, ale nie zawsze dotyczą wytłoczonego z niego oleju.

\section{Alternatywne podejście do diety roślinnej - Eco-Atkins}

W większości przypadków diety roślinne są bogate w węglowodany, umiarkowanie białkowe oraz niskotłuszczowe. Nie jest to jednak reguła. Szczególnie interesującą odmianą diety roślinnej jest tak zwana Eco-Atkins, czyli niskowęglowodanowa, wysokobiałkowa i wysokotłuszczowa dieta oparta na produktach sojowych, w tym tofu, i analogach mięsa, przetworach z glutenu, orzechach oraz olejach roślinnych. Nazwa nawiązuje do wysokobiałkowej, wysokotłuszczowej i ubogiej w węglowodany diety autorstwa amerykańskiego kardiologia Roberta Atkinsa, której podstawą są wysokobiałkowe produkty pochodzenia zwierzęcego i tłuszcz.

Po raz pierwszy dietę tę przebadali w 2009 roku Jenkins i wsp. [67]. Porównywano ją z wysokowęglowodanową dietą laktoowowegetariańską. Po 4 tygodniach stosowania zmniejszenie masy ciała było podobne w obu grupach, jednak obniżenie stężenia cholesterolu było bardziej widoczne w grupie przestrzegającej diety Eco-Atkins. W 2014 roku powtórzono badanie, przy czym czas trwania przedłużono do 6 miesięcy [68]. W przypadku Eco-Atkins stwierdzono większy spadek masy ciała (6,9 v. 5,8 kg) oraz większą redukcję stężeń cholesterolu frakcji LDL i triglicerydów. Zauważono również bardziej korzystne zmiany w proporcji apolipoprotein A-I i B.

Wnioski z badań nad Eco-Atkins znajdują potwierdzenie $w$ badaniach epidemiologicznych. $W$ badaniach kohortowych, obejmujących okres 20 lat oraz 85168 kobiet i 44548 mężczyzn, stwierdzono, że niskowęglo- 
wodanowa dieta oparta na produktach roślinnych może zmniejszać umieralność z wszystkich przyczyn, w tym sercowo-naczyniowych, w porównaniu z dietą niskowęglowodanową opartą na produktach zwierzęcych [69]. Jednocześnie zaobserwowano, że dieta niskowęglowodanowa bogata w produkty zwierzęce w porównaniu z typową dietą zwiększa śmiertelność.

Eco-Atkins wydaje się wartościowym połączeniem diety roślinnej i niskowęglowodanowej. Wiąże się z długoterminowym bezpieczeństwem stosowania oraz zmniejszeniem masy ciała i stężenia LDL charakterystycznym dla diet roślinnych oraz nie podwyższa wartości triglicerydów ani nie obniża stężenia HDL, co jest typowe dla diet wysokowęglowodanowych. Ponadto może być bardziej atrakcyjna z punktu widzenia pacjenta niż niskotłuszczowa dieta roślinna.

\section{Podsumowanie}

W świetle obecnej wiedzy naukowej włączenie większej ilości produktów roślinnych, takich jak warzywa strączkowe, w tym soja i jej przetwory, zbożowe produkty pełnoziarniste, warzywa i owoce oraz orzechy, powoduje obniżenie ryzyka chorób układu sercowo-naczyniowego. Natomiast niektóre produkty odzwierzęce, szczególnie czerwone i przetworzone mięso oraz tłusty nabiał i masło spożywane w większych ilościach, sprzyjają rozwojowi chorób układu krążenia. Związek między chorobami układu sercowo-naczyniowego a spożyciem jaj przez osoby zdrowe jest niejednoznaczny. Również wnioski z obserwacji prowadzonych u osób przestrzegających diet roślinnych - wegetariańskich i wegańskich - sugerują, że ograniczenie żywności odzwierzęcej jest korzystne. Istnieją również doświadczenia, w których wykazano, że dieta bogata w produkty roślinne, szczególnie niskoprzetworzone, przynosi poprawę kontroli czynników ryzyka chorób układu sercowo-naczyniowego. Należy zwrócić uwagę, że mimo korzyści z diet roślinnych w przypadku ich stosowania istnieje ryzyko niedoboru witaminy $\mathrm{B}_{12}$ i kwasów omega 3. Również dieta roślinna może być oparta na produktach zwiększających ryzyko chorób układu sercowo-naczyniowego, takich jak rafinowane węglowodany oraz tłuszcze trans - jej protekcyjny lub terapeutyczny efekt $w$ dużej mierze będzie zależał od właściwego skomponowania.

Odpowiednio skomponowana dieta roślinna powinna być rozważana zarówno jako narzędzie do zapobiegania, jak i wspomagania leczenia chorób układu sercowo-naczyniowego. Jeżeli jest to niemożliwe lub nieakceptowane przez pacjenta, to korzystne pozostaje włącznie do diety produktów roślinnych w celu częściowego zastąpienia produktów zwierzęcych, w szczególności takich jak orzechy, większej ilości owoców i warzyw oraz warzyw strączkowych zamiast mięs.

\section{Podziękowanie}

Dziękuję Jakubowi Sobieckiemu za krytyczne uwagi i wskazówki podczas tworzenia niniejszego artykułu.

\section{Konflikt interesów}

Brak konfliktu interesów.

\section{Abstract}

The solution for growing problem of cardiovascular diseases is one of the main tasks of the modern science of human nutrition. The relation between a cardiovascular disease and a diet has been extensively studied. The harmful effect is attributed to a diet rich in saturated fatty acids and cholesterol and to large supply of salt and sucrose. Epidemiological data suggest that vegans and vegetarians suffer less from cardiovascular system diseases, than those who are on a diet allowing animal products. What is more, the experimental data indicate the therapeutic effect of plant-based diets. The problem is of a complex nature - a number of factors and nutrition products can have an impact on the development of the disease. Furthermore, apart from the positive aspects of plant-based diets, they may be associated with increased exposure to certain risk factors such as hyperhomocysteinaemia caused by a deficiency of cobalamin (vitamin $\mathrm{B}_{12}$ ), and poor nutritional status of long-chain polyunsaturated omega-3 fatty acids.

Key words: vegetarianism, veganism, plant-based diet, atherosclerosis, cardiovascular diseases, cholesterol

(Folia Cardiologica 2015; 10, 2: 92-99) 


\section{Piśmiennictwo}

1. Majewicz A., Marcinkowski J.T. Epidemiologia chorób układu krążenia. Dlaczego w Polsce jest tak małe zainteresowanie istniejącymi programami profilaktycznymi? Probl. Hig. Epidemiol. 2012; 89: 322-325.

2. Huang T., Yang B., Zheng J. i wsp. Cardiovascular disease mortality and cancer incidence in vegetarians: a meta-analysis and systematic review. Ann. Nutr. Metab. 2012; 60: 233-240. doi:10.1159/000337301.

3. Bradbury K.E., Crowe F.L., Appleby P.N. i wsp. Serum concentrations of cholesterol, apolipoprotein A-I and apolipoprotein B in a total of 1694 meat-eaters, fish-eaters, vegetarians and vegans. Eur. J. Clin. Nutr. 2014; 68: 178-183. doi:10.1038/ejcn.2013.248.

4. Yang S.-Y., Li X.-J., Zhang W. i wsp. Chinese lacto-vegetarian diet exerts favorable effects on metabolic parameters, intima-media thickness, and cardiovascular risks in healthy men. Nutr. Clin. Pract. 2012; 27: 392-398. doi:10.1177/0884533611436173.

5. De Groot E., Hovingh G.K., Wiegman A. i wsp. Measurement of arterial wall thickness as a surrogate marker for atherosclerosis. Circulation 2004; 109 (23 supl. 1): III33-III38. doi:10.1161/01. CIR.0000131516.65699.ba.

6. Ornish D., Scherwitz L.W., Billings J.H. i wsp. Intensive lifestyle changes for reversal of coronary heart disease. JAMA 1998; 280: 2001-2007. doi:10.1001/jama.280.23.2001.

7. Ornish D., Brown S.E.E., Scherwitz L.W.W. i wsp. Can lifestyle changes reverse coronary heart disease? Lancet 1990; 336: 129-133. doi:10.1016/0140-6736(90)91656-U.

8. Barnard N.D., Scialli A.R., Bertron P. i wsp. Effectiveness of a low-fat vegetarian diet in altering serum lipids in healthy premenopausal women. Am. J. Cardiol. 2000; 85: 969-972. doi:10.1016/S00029149(99)00911-X.

9. Mishra S., Xu J., Agarwal U. i wsp. A multicenter randomized controlled trial of a plant-based nutrition program to reduce body weight and cardiovascular risk in the corporate setting: the GEICO study. Eur. J. Clin. Nutr. 2013; 67: 718-724. doi:10.1038/ejcn.2013.92.

10. Barnard N., Cohen J. A low-fat vegan diet improves glycemic control and cardiovascular risk factors in a randomized clinical trial in individuals with type 2 diabetes. Diabetes Care 2006; 29: 1777-1783. doi:10.2337/dc06-0606.

11. Barnard N.D., Cohen J., Jenkins D.J.A. i wsp. A low-fat vegan diet and a conventional diabetes diet in the treatment of type 2 diabetes: a randomized, controlled, 74-wk clinical trial. Am. J. Clin. Nutr. 2009; 89: 1588-1596. doi:10.3945/ajcn.2009.26736H.

12. Kahleova H., Matoulek M., Malinska H. i wsp. Vegetarian diet improves insulin resistance and oxidative stress markers more than conventional diet in subjects with type 2 diabetes. Diabet. Med. 2011; 28 : 549-559. doi:10.1111/j.1464-5491.2010.03209.x.

13. Rohrmann S., Overvad K., Bueno-de-Mesquita H.B. i wsp. Meat consumption and mortality - results from the European Prospective Investigation into Cancer and Nutrition. BMC Med. 2013; 11: 63. doi:10.1186/1741-7015-11-63.

14. Sinha R., Cross A.J., Graubard B.I. i wsp. Meat intake and mortality: a prospective study of over half a million people. Arch. Intern. Med. 2009; 169: 562-571. doi:10.1001/archinternmed.2009.6.

15. Wang Y., Beydoun M.A. Meat consumption is associated with obesity and central obesity among US adults. Int. J. Obes. (Lond.) 2009; 33: 621-628. doi:10.1038/ijo.2009.45.

16. Vergnaud A.-C., Norat T., Romaguera D. i wsp. Meat consumption and prospective weight change in participants of the EPIC-PANACEA study. Am. J. Clin. Nutr. 2010; 92: 398-407. doi:10.3945/ajcn.2009.28713.
17. Pan A., Sun Q., Bernstein A.M. i wsp. Red meat consumption and risk of type 2 diabetes: 3 cohorts of US adults and an updated meta-analysis. Am. J. Clin. Nutr. 2011; 94: 1088-1096. doi:10.3945/ /ajcn.111.018978.

18. European Food Safety Authority. Scientific Opinion on Dietary Reference Values for fats, including saturated fatty acids, polyunsaturated fatty acids, monounsaturated fatty acids, trans fatty acids, and cholesterol. EFSA J. 2010; 8: 1-107. doi:10.2903/j.efsa.2010.1461.

19. Ussher J.R., Lopaschuk G.D., Arduini A. Gut microbiota metabolism of L-carnitine and cardiovascular risk. Atherosclerosis 2013; 231 : 456-461. doi:10.1016/j.atherosclerosis.2013.10.013.

20. Tang W.H.W., Wang Z., Levison B.S. i wsp. Intestinal microbial metabolism of phosphatidylcholine and cardiovascular risk. N. Engl. J. Med. 2013; 368: 1575-1584. doi:10.1056/NEJMoa1109400.

21. DiNicolantonio J.J., Lavie C.J., Fares H. i wsp. L-carnitine in the secondary prevention of cardiovascular disease: systematic review and meta-analysis. Mayo Clin. Proc. 2013; 88: 544-551. doi:10.1016/j. mayocp.2013.02.007.

22. Fernandez-Cao J.C., Arija V., Aranda N. i wsp. Heme iron intake and risk of new-onset diabetes in a Mediterranean population at high risk of cardiovascular disease: an observational cohort analysis. BMC Public Health. 2013; 13: 1042. doi:10.1186/1471-2458-13-1042.

23. Basuli D., Stevens R.G., Torti F.M. i wsp. Epidemiological associations between iron and cardiovascular disease and diabetes. Front. Pharmacol. 2014; 5: 117. doi:10.3389/fphar.2014.00117.

24. Fernandez-Real J.M., Penarroja G., Castro A. i wsp. Blood letting in high-ferritin type 2 diabetes: effects on insulin sensitivity and cell function. Diabetes 2002; 51: 1000-1004. doi:10.2337/diabetes.51.4.1000.

25. Huth P.J., Park K.M. Influence of dairy product and milk fat consumption on cardiovascular disease risk: a review of the evidence. Adv. Nutr. 2012; 3: 266-285. doi:10.3945/an.112.002030.

26. Weggemans R.M., Zock P.L., Katan M.B. Dietary cholesterol from eggs increases the ratio of total cholesterol to high-density lipoprotein cholesterol in humans: a meta-analysis. Am. J. Clin. Nutr. 2001; 73: 885-891.

27. Li Y., Zhou C., Zhou X. i wsp. Egg consumption and risk of cardiovascular diseases and diabetes: a meta-analysis. Atherosclerosis 2013; 229: 524-530.

28. Shin J.Y., Xun P., Nakamura Y. i wsp. Egg consumption in relation to risk of cardiovascular disease and diabetes: a systematic review and meta-analysis. Am. J. Clin. Nutr. 2013; 98: 146-159. doi:10.3945/ /ajcn.112.051318.

29. Rong Y., Chen L., Zhu T. i wsp. Egg consumption and risk of coronary heart disease and stroke: dose-response meta-analysis of prospective cohort studies. BMJ 2013; 346: e8539. doi:10.1136/bmj.e8539.

30. Radzevičienè L., Ostrauskas R. Egg consumption and the risk of type 2 diabetes mellitus: a case-control study. Public Health Nutr. 2012; 15 : 1437-1441. doi:10.1017/S1368980012000614.

31. Djoussé L., Kamineni A. Egg consumption and risk of type 2 diabetes in older adults. Am. J. Clin. Nutr. 2010; 92: 422-427. doi:10.3945/ /ajcn.2010.29406.

32. Djoussé L., Gaziano J., Buring J. i wsp. Egg consumption and risk of type 2 diabetes in men and women. Diabetes Care 2009; 32: e73. doi:10.2337/dc09-0159.

33. Bazzano L.A., Thompson A.M., Tees M.T. i wsp. Non-soy legume consumption lowers cholesterol levels: a meta-analysis of randomized controlled trials. Nutr. Metab. Cardiovasc. Dis. 2011; 21: 94-103. doi:10.1016/j.numecd.2009.08.012. 
34. Sacks F.M., Lichtenstein A., Van Horn L. i wsp. Soy protein, isoflavones, and cardiovascular health: an American Heart Association Science Advisory for professionals from the Nutrition Committee. Circulation 2006; 113: 1034-1044. doi:10.1161/CIRCULATIONAHA.106.171052.

35. Afshin A., Micha R., Khatibzadeh S. i wsp. Consumption of nuts and legumes and risk of incident ischemic heart disease, stroke, and diabetes: a systematic review and meta-analysis. Am. J. Clin. Nutr. 2014; 100: 278-288. doi:10.3945/ajcn.113.076901.

36. Reynolds K., Chin A., Lees K.A. i wsp. A meta-analysis of the effect of soy protein supplementation on serum lipids. Am. J. Cardiol. 2006; 98 : 633-640. doi:10.1016/j.amjcard.2006.03.042.

37. Reverri E.J., LaSalle C.D., Franke A.A. i wsp. Soy provides modest benefits on endothelial function without affecting inflammatory biomarkers in adults at cardiometabolic risk. Mol. Nutr. Food Res. 2015; 59: 323-333. doi: 10.1002/mnfr.201400270.

38. Cho S.S., Qi L., Fahey G.C. i wsp. Consumption of cereal fiber, mixtures of whole grains and bran, and whole grains and risk reduction in type 2 diabetes, obesity, and cardiovascular disease. Am. J. Clin. Nutr. 2013; 98: 594-619. doi:10.3945/ajcn.113.067629.

39. Mellen P.B., Walsh T.F., Herrington D.M. Whole grain intake and cardiovascular disease: a meta-analysis. Nutr. Metab. Cardiovasc. Dis. 2008; 18: 283-290. doi:10.1016/j.numecd.2006.12.008.

40. Behall K.M., Scholfield D.J., Hallfrisch J. Whole-grain diets reduce blood pressure in mildly hypercholesterolemic men and women. J. Am. Diet. Assoc. 2006; 106: 1445-1449. doi:10.1016/j.jada.2006.06.010.

41. Fardet A. New hypotheses for the health-protective mechanisms of whole-grain cereals: what is beyond fibre? Nutr. Res. Rev. 2010; 23 : 65-134. doi:10.1017/S0954422410000041.

42. Hartley L., Igbinedion E., Holmes J. i wsp. Increased consumption of fruit and vegetables for the primary prevention of cardiovascular diseases. Cochrane Database Syst. Rev. 2013; 6: CD009874. doi:10.1002/14651858.CD009874.pub2.

43. Wang X., Ouyang Y., Liu J. i wsp. Fruit and vegetable consumption and mortality from all causes, cardiovascular disease, and cancer: systematic review and dose-response meta-analysis of prospective cohort studies. BMJ. 2014; 349: g5472. doi:10.1136/bmj.g5472.

44. Appel L.J., Moore T.J., Obarzanek E. i wsp. A clinical trial of the effects of dietary patterns on blood pressure. DASH Collaborative Research Group. N. Engl. J. Med. 1997; 336: 1117-1124. doi:10.1056/ /NEJM199704173361601.

45. Bao Y., Han J., Hu F.B. i wsp. Association of nut consumption with total and cause-specific mortality. N. Engl. J. Med. 2013; 369: 2001-2011. doi:10.1056/NEJMoa1307352.

46. Mukuddem-Petersen J., Oosthuizen W., Jerling J.C. A systematic review of the effects of nuts on blood lipid profiles in humans. J. Nutr. 2005; 135: 2082-2089.

47. Sabaté J., Oda K., Ros E. Nut consumption and blood lipid levels: a pooled analysis of 25 intervention trials. Arch. Intern. Med. 2010; 170: 821-827. doi:10.1001/a rchinternmed.2010.79.

48. Maranhão P.A., Kraemer-Aguiar L.G., de Oliveira C.L. i wsp. Brazil nuts intake improves lipid profile, oxidative stress and microvascular function in obese adolescents: a randomized controlled trial. Nutr. Metab. (Lond.) 2011; 8: 32. doi:10.1186/1743-7075-8-32.

49. Colpo E., Vilanova C.D.D.A., Brenner Reetz L.G. i wsp. A single consumption of high amounts of the Brazil nuts improves lipid profile of healthy volunteers. J. Nutr. Metab. 2013; 2013: 653185. doi:10.1155/2013/653185.

50. Katz D.L., Davidhi A., Ma Y. i wsp. Effects of walnuts on endothelial function in overweight adults with visceral obesity: a randomized, controlled, crossover trial. J. Am. Coll. Nutr. 2012; 31: 415-423.
51. West S.G., Krick A.L., Klein L.C. i wsp. Effects of diets high in walnuts and flax oil on hemodynamic responses to stress and vascular endothelial function. J. Am. Coll. Nutr. 2010; 29: 595-603.

52. Orem A., Yucesan F.B., Orem C. i wsp. Hazelnut-enriched diet improves cardiovascular risk biomarkers beyond a lipid-lowering effect in hypercholesterolemic subjects. J. Clin. Lipidol. 2013; 7: 123-131. doi:10.1016/j.jacl.2012.10.005.

53. Natoli S., McCoy P. A review of the evidence: nuts and body weight. Asia Pac. J. Clin. Nutr. 2007; 16: 588-597.

54. Martínez-González M.A., Bes-Rastrollo M. Nut consumption, weight gain and obesity: Epidemiological evidence. Nutr. Metab. Cardiovasc. Dis. 2011; 21 (supl. 1:) S40-S45. doi:10.1016/j.numecd.2010.11.005.

55. Mattes R.D., Kris-Etherton P.M., Foster G.D. Impact of peanuts and tree nuts on body weight and healthy weight loss in adults. J. Nutr. 2008; 138: 1741S-1745S.

56. Jenkins D.J., Kendall C.W., Vidgen E. i wsp. High-protein diets in hyperlipidemia: effect of wheat gluten on serum lipids, uric acid, and renal function. Am. J. Clin. Nutr. 2001; 74: 57-63.

57. Jenkins D.J., Kendall C.W., Vuksan V. i wsp. Effect of wheat bran on serum lipids: influence of particle size and wheat protein. J. Am. Coll. Nutr. 1999; 18: 159-165.

58. Pawlak R., Parrott S.J., Raj S. i wsp. How prevalent is vitamin $B(12)$ deficiency among vegetarians? Nutr. Rev. 2013; 71: 110-117. doi:10.1111/nure.12001.

59. Jarosz M. Normy żywienia dla populacji polskiej: nowelizacja. Instytut Żywności i Żywienia, Warszawa 2012.

60. Woo K., Kwok T., Celermajer D. Vegan diet, subnormal vitamin B-12 status and cardiovascular health. Nutrients 2014; 6: 3259-3273. doi:10.3390/nu6083259.

61. Lane K., Derbyshire E., Li W. i wsp. Bioavailability and potential uses of vegetarian sources of omega-3 fatty acids: a review of the literature. Crit. Rev. Food Sci. Nutr. 2014; 54: 572-579. doi:10.1080/104083 98.2011.596292.

62. Conquer J.A., Holub B.J. Dietary docosahexaenoic acid as a source of eicosapentaenoic acid in vegetarians and omnivores. Lipids 1997; 32: 341-345.

63. Rodriguez-Leyva D., Weighell W., Edel A.L. i wsp. Potent antihypertensive action of dietary flaxseed in hypertensive patients. Hypertension 2013; 62: 1081-1089. doi:10.1161/HYPERTENSIONAHA.113.02094.

64. Pan A., Yu D., Demark-Wahnefried W. i wsp. Meta-analysis of the effects of flaxseed interventions on blood lipids. Am. J. Clin. Nutr. 2009; 90: 288-297. doi:10.3945/ajcn.2009.27469.

65. Rodriguez-Leyva D., Dupasquier C.M.C., McCullough R. i wsp. The cardiovascular effects of flaxseed and its omega-3 fatty acid, alpha-linolenic acid. Can. J. Cardiol. 2010; 26: 489-496.

66. Francis A.A., Deniset J.F., Austria J.A. i wsp. Effects of dietary flaxseed on atherosclerotic plaque regression. Am. J. Physiol. Heart Circ. Physiol. 2013; 304: H1743-H1751. doi:10.1152/ajpheart.00606.2012.

67. Jenkins D.J.A., Wong J.M.W., Kendall C.W.C. i wsp. The effect of a plantbased low-carbohydrate ("Eco-Atkins") diet on body weight and blood lipid concentrations in hyperlipidemic subjects. Arch. Intern. Med. 2009; 169: 1046-1054. doi:10.1001/archinternmed.2009.115.

68. Jenkins D.J.A., Wong J.M.W., Kendall C.W.C. i wsp. Effect of a 6-month vegan low-carbohydrate ('Eco-Atkins') diet on cardiovascular risk factors and body weight in hyperlipidaemic adults: a randomised controlled trial. BMJ Open 2014; 4: e003505. doi:10.1136/bmjopen-2013-003505.

69. Fung T.T., van Dam R.M., Hankinson S.E. i wsp. Low-carbohydrate diets and all-cause and cause-specific mortality: two cohort studies. Ann. Intern. Med. 2010; 153: 289-298. doi:10.7326/0003-4819-153-5 201009070-00003. 